\title{
Confirmed record of the Black jack, Caranx lugubris Poey, 1880 from Lima at the north of the Sea of Oman
}

Laith A. Jawad

Marine Science and Fisheries Centre, Ministry of Agriculture and Fisheries Wealth, P. O. Box 427, Postal Code 100 Muscat, Oman.

\section{Resumen}

Correspondence

L.A. Jawad

E-mail: laith_jawad@hotmail.com

Received: 5 September 2012

Accepted: 31 October 2012

Published on-line: 19 November 2012
Captura confirmada de jurel negro, Caranx lugubris Poey, 1880 en Lima, Golfo de Omán

Se reporta la primea cita de Caranx lugubris en el Golfo de Omán, basada en un espécimen de $670 \mathrm{~mm}$ de longitud. Éste se capturó en aguas cercanas a la ciudad de Lima, en el norte del Golfo de Omán. Esta cita representa la captura más septentrional de esta especie en el océano Índico. La longitud estándar se compara con la de especímenes capturadas en las costas de Laquedivas, Okinawa, Isla de Pascua y Taiwan.

Palabras clave: Nueva cita, Carangidae, Golfo de Omán.

\begin{abstract}
The first record of Caranx lugubris in the Sea of Oman is reported based on one specimen $670 \mathrm{~mm}$ in total length. The specimen obtained from waters around City of Lima at the north the Sea of Oman. This account represents the north most record of this species in the Indian Ocean region. The standard length is compared with specimens caught from the coasts of Lacadives, Okinawa, Easter Island and Taiwan.
\end{abstract}

Key words: New substancial record, new extension, Carangidae, Sea of Oman, Sultanate of Oman.

\section{Introduction}

The Family Carangidae includes ecologically and economically important species such as the jacks, scads, trevallies, pampano, amberjacks and queenfishes. These species live in diverse marine habitats, found in all tropical and subtropical marine waters of the world, and some occur in temperate regions and acquire different body shapes ranging from deep bodied of the neretic bottom feeders to the more slender neretic planktivores (Nair et al. 1990). In Oman, fishes of the Family Carangidae are widely distributed along the coasts of Sea of Oman and the Arabian Sea coasts of Oman. During 2010, an estimated $5400 \mathrm{t}$ of carangids were landed from the Omani waters in general (Mi- nistry of Agriculture and Fisheries Statistics, 2011).

The Family Carangidae consists of 710 species belonging to 124 genera (Eschmeyer, 2012). In Omani waters, this family consists of 48 species belonging to 21 genera (Randall, 1995) while in the Arabian Sea coasts of Oman alone this family showed to comprise 46 species belonging to 20 genera (L.A. Jawad, unpublished data).

Lacépède (1801) has established the genus Caranx and assigned the species $C$. carangua Lacépède as type-species. The genus Caranx consists of 278 valid species (Eschmeyer 2012). In Omani waters, there are five species belonging to this genus (Randall 1995, L.A. Jawad, unpublished data). 
C. lugubris has a circumtropical distribution. Randall (1995) reported this species among the coastal fishes of Oman, but he did not specify exactly where from in Oman he collected this species, thus it is left open to where to find $C$. lugubris in Oman. On the other hand, Al-Jifaili et al. (2010) reported C. lugubris from waters of Oman and as in the case of Randall (1995), they did not state the area of collection. Oman is situated on three major seas, the Arabian Gulf (Persian Gulf), the Sea of Oman and the Arabian Sea. Each of these seas has its own zoogeographic entity and peculiar fish fauna. Therefore, in case of Al-Jufaili et al. (2010) it is important to specify from which sea their specimens were obtained. The present study confirms the presence of this species in the Sea of Oman and record the north most range extension of this species in the Indian Ocean.

\section{Material and methods}

On $7^{\text {th }}$ May 2011, a catch of Black jack, Caranx lugubris Poey, 1880 (Fig. 1) was recorded from the coasts of the city of Lima at the north most of the Sea of Oman where a local fisherman captured one specimen with gill net (Fig. 2). Age of the specimen was estimated from the scales taken from different body areas for age verification. Dissecting microscope was used in the study of the stomach content and determination of the mat- uration stage. Morphometric and meristic details were recorded following (Smith-Vaniz \& Carpenter 2007); the data are presented in table 1. The specimen was deposited in the fish collection of the Marine Science and Fisheries Centre, Ministry of Fisheries Wealth, Muscat, Sultanate of Oman, catalogue number OMMSTC 1090.

\section{Results and description}

The specimen obtained in the present work was matured male with riped gonad at its $2^{\text {nd }}$ stage of maturation and in its third year of lie. The stomach content showed that the specimen was fed mainly on small pelagic fish species such as sardines and crustacea. To make the results of the present work more informative, an attempt was made o locate the specimens of $C$. lugubris reported to be collected by Al-Jufaili et al. (2010). No specimens were found, therefore comparison with the present specimen become impossible.

C. lugubris is characterized in having the following set of characters: in large specimens, predorsal profile with concavity in front of nostril and angularly curved at occipital, otherwise it is steep. Snout obtuse, longer than eye diameter. Anterior lateral line strongly curved, becoming straight below 3rd-4th rays of 2 nd dorsal fin. Breast completely scaly. Color in life, body and fin uniform grey to black. A small opercular spot present.

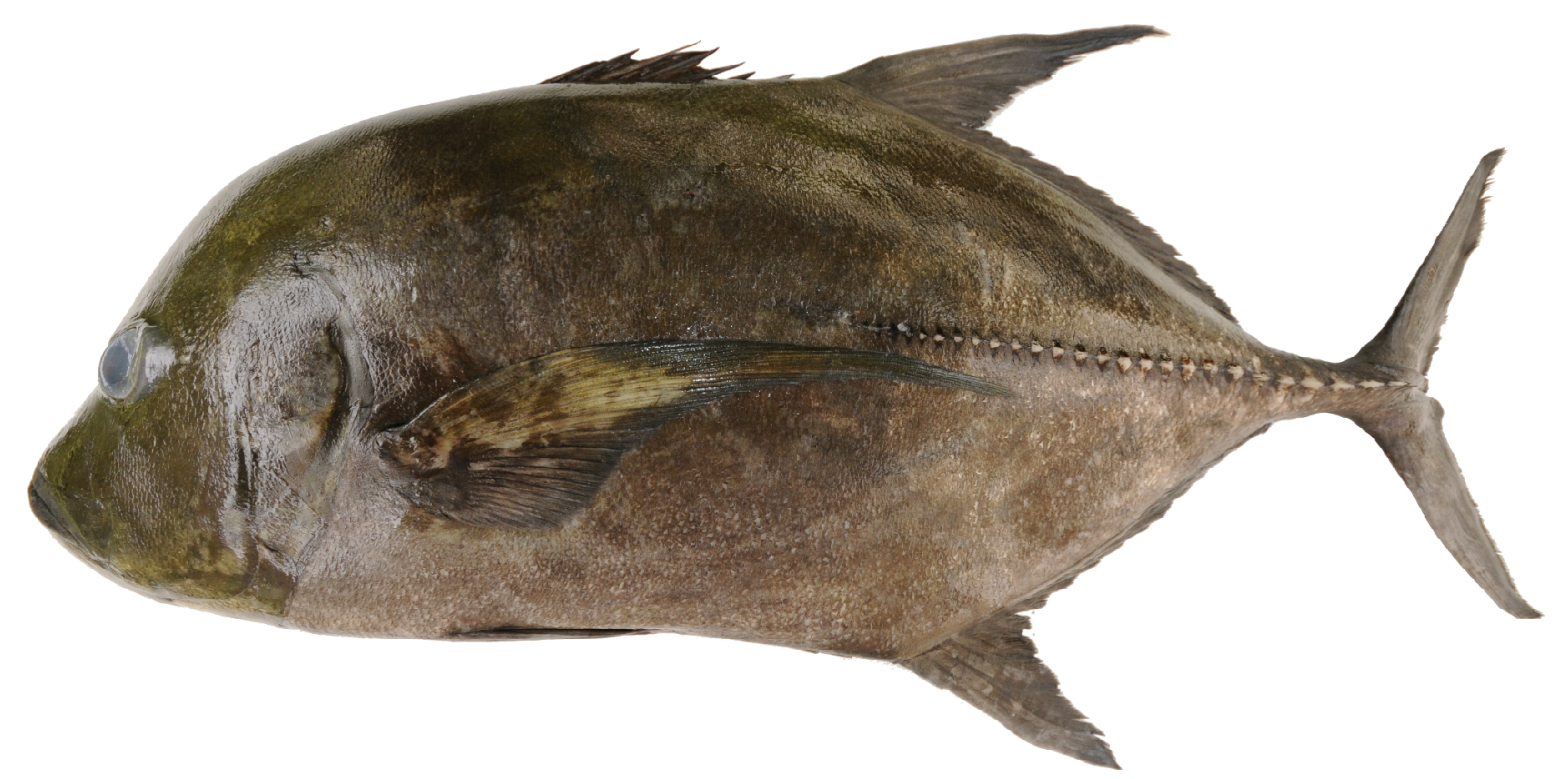

Figura 1. Caranx lugubris, OMMSFC 1090, 670 mm longitud total. Capturado en las costas de Lima, norte del Golfo de Omán, 7-V- 2011, por un pescador empleando red de enmalle.

Figure 1. Caranx lugubris, OMMSFC 1090, $670 \mathrm{~mm}$ total length, caught at the coasts of the City of Lima, north of the Sea of Oman, 7-V2011, collected by fisherman using gill net. 


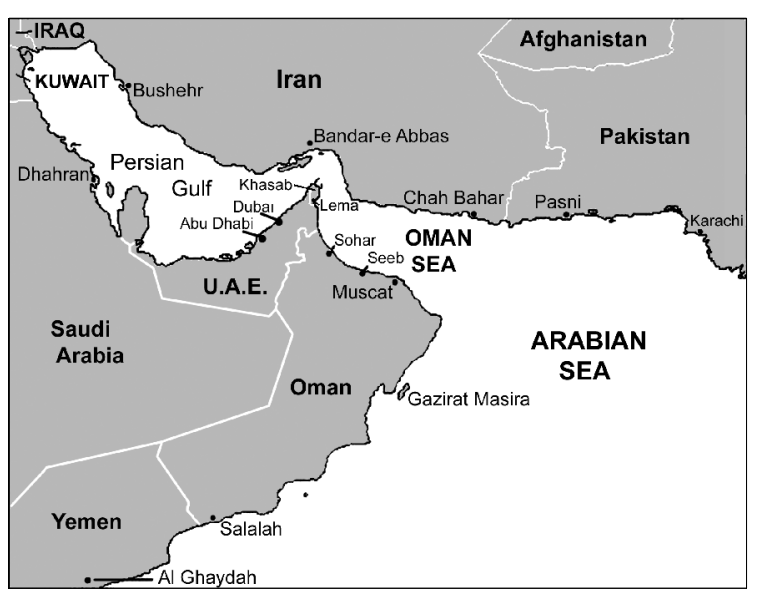

Figura 2. Mapa mostrando el lugar de captura del ejemplar de Caranx lugubris.

Figure 2. Map showing the collection site of the specimen of Caranx lugubris.

This species is distinguished from the congener Caranx species occurring in the area in having breast completely scaled where it is partially naked in other species; in adults, height of dorsal fin lobe usually long; body and fins essentially uniform grey to brown, with a small dark spot at upper end of opercle often present (Fischer \& Bianchi 1984).

As far as the authors are aware, few specimens of $C$. lugubris have been provided only with total length, standard length or forked length and they are available in fish collections around the world: 265-277 mm total length, Lacadives (Jones \& Kumaran 1966); 248mm standard length, Okinawa (Gushiken 1988); 380-650mm forked length, Easter Island (Randall, 1995); $338 \mathrm{~mm}$ forked length, Taiwan (Lin \& Shao 1999). The three fish lengths (total, standard and forked lengths) of the specimen obtained in the present study are larger than any of the specimens obtained by above mentioned.

With only one large-sized specimen of $C$. lugubris, it is premature to consider that this species has established a sustainable population in its new region. Thus, there is a need to investigate further the frequency of occurrence and to study the biological characteristics of this species in order to determine its establishment. However, the presence of this species in the identified location may be explained by a lack of sufficient ichthyological expeditions and surveys to detect rare species.

\section{Acknowledgements}

I would also like to thank the Ministry of Fisheries Wealth, Marine Science and Fisheries Centre, Ministry of Fisheries Wealth and the directorate of Agriculture and Fisheries Developmental Fund for giving me the opportunity to work on the fish samples within the qualitative and quantitative distribution of marine organisms in Sultanate of Oman and to provide the appropriate financial support. My sincere thanks are also due to William Smith-Vaniz, Florida Museum of Natural History, for the identification.

\section{References}

Al-Jufaili SM, Hermoza G, Al-Shuaily S S \& Al-Mujaini A. 2010 Oman fish biodiversity. Journal of King Abdul Aziz University, Marine Science, 21: 3-51.

Eschmeyer WN. (ed.) 2012 Catalog of fishes. Version of June 2007. Available from http:// www.fishbase .org (Accessed June 2012).

Fischer W \& Bianchi G (eds.). 1984 FAO species identification sheets for fishery purposes. Western Indian Ocean (Fishing area 51). Prepared and printed with the support of the Danish International Development Agency (DANIDA). Rome, Food and Agricultural Organization of the United nation, Vol. IV, Fam. Scatophagidae to Trichiuridae. Available from http:// www.fao.org/docrep/009/ad468e/ad468e00.HTM (Accessed June 2012)

Gushiken S. 1988 Phylogenetic relationships of the perciform genera of the family Carangidae. Japanese Journal of Ichthyology, 34: 443-461.

Jones S \& Kumaran M. 1966 New records of fishes from the seas around India, Part IV. Marine Biological Association of India, 8: 163-180

Lacépède BGE. 1801 Histoire naturelle des poissons. 3: 558 p. Plassan, Paris.

Lin PL, Shao KT. 1999A review of the carangid fishes (Family: Carangidae) from Taiwan with descriptions of four new records. Zoological Studies, 38: 33-68.

Ministry of Agriculture and Fisheries Statistics. 2011 Fisheries statistic book for the year 2011. Ministry of Agriculture and Fisheries, Muscat, Oman, 123pp.

Nair RJ., Jishi KK, Kuriakose S \& Geetha P M. 1990 A Study on the diversity of carangid resources off Cochin, Kerala, India. Report, Central Marine Fisheries Research Institute, 98-108p.

Randall JE. 1995 Coastal fishes of Oman. Bathurst, Australia: Crawford House Publishing Pty Ltd, 439pp.

Smith-Vaniz WF \& Carpenter K E. 2007 Review of the crevalle jacks, Caranx hippos complex (Teleostei: Carangidae), with a description of a new species from West Africa. Fishery Bulletin, 105:207-233. 